\title{
PENGARUH MOTIVASI DAN KOMPENSASI TERHADAP KEPUASAN KERJA KARYAWAN PADA KANTOR PT. PLN (PERSERO) AREA PEMATANGSIANTAR
}

\author{
Oleh: \\ M. Rafi \\ S1 Manajemen \\ Darwin Lie, Marisi Butarbutar, Efendi
}

Abstraksi

Hasil penelitian dapat disimpulkan sebagai berikut: 1) Motivasi yang diberikan sudah baik dan karyawan setuju dengan kompensasi yang diberikan serta karyawan sudah puas terhadap kepuasan kerja. 2) Hasil analisis regresi adalah $\hat{Y}=43,983+0,424 X_{1}+0,253 X_{2}$, artinya motivasi dan kompensasi berpengaruh positif terhadap kepuasan kerja karyawan. 3) Hasil analisis korelasi diperoleh nilai $r=0,524$ artinya terdapat hubungan yang sedang dan positif antara motivasi, kompensasi terhadap kepuasan kerja. Nilai koefisien determinasi (R Square) sebesar 0,275 artinya tinggi rendahnya kepuasan kerja karyawan dapat dijelaskan oleh motivasi dan kompensasi sebesar 27,5\%. 4) Hipotesis penelitian $\mathrm{H}_{0}$ ditolak dan $\mathrm{H}_{a}$ diterima, artinya motivasi dan kompensasi berpengaruh positif dan signifikan terhadap kepuasan kerja karyawan pada kantor PT. PLN (Persero) Area Pematangsiantar.

Adapun saran dari penelitian ini adalah untuk meningkatkan motivasi perlu dilakukan pemberian pengetahuan dalam membuat alternatif untuk menjalankan pekerjaan, pimpinan memberikan apresiasi terhadap pelayanan, mengikuti perkembangan teknologi, dan memberikan masukan agar karyawan percaya diri dalam menyelesaikan pekerjaan. Untuk meningkatkan kompensasi perusahaan harus memberikan gaji sesuai dengan jabatan dan pekerjaan yang dilakukan, memberikan pengarahan dan bimbingan, memberikan bonus tepat pada waktunya, memberikan tunjangan secara adil dan layak. Memperbaharui fasilitas kantor yang sudah usang, dan memberikan asuransi sesuai dengan kebutuhan karyawan. Sedangkan untuk meningkatkan kepuasan kerja karyawan harus memberikan kesempatan promosi atau kenaikan jabatan bagi karyawan yang berprestasi pada Kantor PT PLN (Persero) Area Pematangsiantar.

Kata kunci: Motivasi, Kompensasi dan Kepuasan Kerja Karyawan

\section{Abstraction}

Results of the study can be summarized as follows: 1) Motivation given are good and the employees agree with the compensation given and employees are satisfied with the job satisfaction. 2) The results of the regression analysis is $Y=43.983+0,424 X 1+0,253 X 2$, meaning motivation and compensation positive effect on employee job satisfaction. 3) The results of the analysis obtained correlation value $r=0.524$ means there is $a$ moderate and positive correlation between motivation, compensation for job satisfaction. Later obtained the coefficient of determination ( $R$ Square) of 0.275 means that the level of employee job satisfaction can be explained by the motivation and compensation of $27.5 \%$. 4) The research hypothesis $H_{0}$ is rejected and $H_{a}$ accepted, meaning motivation and compensation positive and significant impact on job satisfaction of employees at the office of PT. PLN (Persero) Area Pematangsiantar.

The suggestion of this research is to increase the motivation necessary to the provision of knowledge in creating an alternative to running the job, leadership provides an appreciation of the service, keep up with technology, and provide input so that employees are confident in completing the work. To enhance the company must provide salary compensation in accordance with the position and the job is done, provide direction and guidance, give bonuses just in time, provide a fair and decent benefits. Renewing obsolete office facilities, and provide insurance in accordance with the needs of employees. Meanwhile, to improve employee job satisfaction should provide the opportunity for promotion or promotion of employees who excel in the Office of PT PLN (Persero) Area Pematangsiantar.

Keywords: Motivation, Compensation and Employee Satisfaction

\section{A. PENDAhuluan}

1. Latar Belakang Masalah

PT. PLN (Persero) merupakan salah satu Badan Usaha Milik Negara (BUMN) yang menyediakan sumber daya energi listrik. Dalam hal ini PT. PLN (Persero) adalah perusahaan yang bergerak dalam bidang jasa dan berkontribusi di bidang pelayanan publik untuk dapat memberikan energi listrik di daerah sekitarnya (khususnya area Pematangsiantar).
Adapun fenomena kepuasan kerja karyawan sementara yang berada di PT. PLN (Persero) Area Pematangsiantar.

Tabel 1

Indikator Kepuasan Kerja Karyawan pada Kantor PT. PLN (Persero) Pematangsiantar

\begin{tabular}{|c|c|c|c|c|c|c|}
\hline 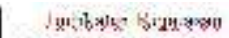 & :11" & $1 i$ & $\mathrm{CH}^{-}$ & 17 & $517:$ & Int \\
\hline Esisi & ses: & 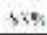 & $12+6$ & " & a & ant \\
\hline 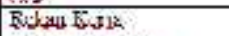 & $2 j^{2} \%$ & $50^{\circ} \mathrm{k}$ & 162 & $2 \%$ & 0 & $300 \%$ \\
\hline 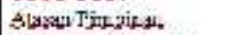 & 32 & $+8 \%$ & 2234 & 0 & 9 & $.00 \%$ \\
\hline wose 13.1 & $15 \%$ & $\leqslant 0$ & $28=$ & $7 \%$ & a & $100 \%$ : \\
\hline Poraos. & $25^{2} \%$ & 1 क्: & $25 \%$ & $5 \%$ & 0 & $-5 x^{2}$ \\
\hline 456458 & 2 & $31^{2}$ & 1826 & $2 \%$ & 2 & $.00 \%$ \\
\hline
\end{tabular}


Sumber: hasil wawancara sementara dengan $\begin{array}{llll}\text { supervisor, } & 20 & \text { Maret } & 2015\end{array}$

PT. PLN (Persero) pada kantor Area Pematangsiantar untuk dapat menciptakan kepuasan kerja karyawannya memberikan motivasi seperti kebutuhan akan prestasi yaitu dengan memberikan kebebasan bagi karyawannya untuk mencari pengetahuan yang luas agar dapat meningkatkan prestasi kerja. Kebutuhan akan afiliasi adalah dengan memberikan penghargaan dan tunjangan atas prestasi kerja yang tinggi. Kebutuhan akan kekuasan, dalam hal ini perusahaan memberikan kesempatan promosi kenaikan jabatan bagi karyawan yang berprestasi agar dapat mendorong semangat dalam bekerja. Faktor lainnya untuk mencapai kepuasan kerja karyawan tersebut yaitu pemberian kompensasi.

PT. PLN (Persero) Area Pematangsiantar menyadari bahwa diperlukan sumberdaya manusia yang memiliki motivasi yang kuat untuk dapat memenuhi tujuan perusahaan dan tuntutan pelanggannya. Karena karyawan merupakan salah satu unsur terpenting, maka hal-hal yang berhubungan seperti kompensasi yang diberikan perusahaan kepada karyawan dapat memberikan kepuasan tersendiri dan karyawan tersebut lebih bersemangat dalam bekerja. Kepuasan kerja dapat terjadi apabila motivasi dan kompensasi yang diberikan, sesuai dengan pekerjaan yang dilakukan dan kebutuhan karyawan.

\section{Rumusan Masalah}

a. Bagaimana gambaran motivasi, kompensasi dan kepuasan kerja karyawan pada Kantor PT. PLN (Persero) Area Pematangsiantar?

b. Bagaimana pengaruh motivasi dan kompensasi terhadap kepuasan kerja karyawan pada Kantor PT. PLN (Persero) Area Pematangsiantar baik secara simultan maupun parsial.

\section{Tujuan Penelitian}

a. Untuk mengetahui gambaran motivasi, kompensasi dan kepuasan Kerja karyawan pada kantor PT. PLN (Persero) Area Pematangsiantar.

b. Untuk mengetahui pengaruh motivasi dan kompensasi terhadap kepuasan kerja karyawan pada kantor PT. PLN (Persero) Area Pematangsiantar baik secara simultan maupun parsial.

\section{Metode Penelitian}

Dalam penelitian ini, penulis mengambil objek penelitian pada PT. PLN (Persero) Area Pematangsiantar yang terletak di Jalan Kapten M.H. Sitorus No.1 Pematangsiantar. Sampel yang digunakan penulis adalah seluruh karyawan yang berada dikantor PT. PLN (Persero) Area Pematangsiantar yaitu sebanyak 68 orang.

Adapun Desain penelitian yang digunakan dalam penulisan penelitian ini adalah Penelitian Kepustakaan (Library Research) dan Penelitian Lapangan (Field Research). Teknik pengumpulan data yang dilakukan penulis dalam penelitian ini adalah berupa Kuesioner, Wawancara dan Dokumentasi. Adapun jenis data yang digunakan dalam penelitian ini adalah jenis data kualitatif dan data kuantitatif. Hasil data yang diperoleh dari lapangan akan dianalisis secara deskriptif baik bersifat kualitatif dan kuantitatif.

\section{B. LANDASAN TEORI}

1. Manajemen Sumber Daya Manusia

Menurut Mondy (2008:10), manajemen sumber daya manusia adalah pemanfaatan sejumlah individu untuk mencapai tujuan-tujuan organisasi. Sedangkan menurut Dessler (2007:2), manajemen sumber daya manusia adalah kebijakan dan cara-cara yang dipraktekkan dan berhubungan dengan pemberdayaan manusia atau aspek-aspek sumber daya manusia dari sebuah posisi manajemen termasuk perekrutan, seleksi, pelatihan, penghargaan, dan penilaian. Berdasarkan pendapat beberapa para ahli di atas, penulis menyimpulkan bahwa manajemen sumber daya manusia adalah suatu proses yang mengatur menjalankan kegiatan dengan baik dan benar dengan pemberdayaan manusia untuk dapat menunjang aktivitas organisasi atau perusahaan demi mencapai tujuan yang telah ditetapkan.

\section{Motivasi}

Menurut Luthans (2006:270), motivasi adalah keadaan dalam diri individu yang memunculkan, mengarahkan, dan mempertahankan perilaku. Menurut Robbins (2003:156), menyatakan motivasi sebagai proses yang menyebabkan intensitas (intensity), arah (direction), dan usaha terus menerus (persistence) individu menuju pencapaian tujuan. Dari beberapa pendapat ahli diatas, maka dapat disimpulkan bahwa motivasi yaitu dorongan yang mempengaruhi dan mengarahkan karyawan untuk melakukan kegiatan tertentu guna mencapai tujuan secara berhasil.

\section{Kompensas}

Menurut Mondy (2008:4), kompensasi adalah total seluruh imbalan yang diterima para karyawan sebagai pengganti jasa yang telah mereka berikan. Sedangkan menurut Griffin (2004:432), kompensasi adalah renumerasi finansial yang diberikan oleh orang kepada karyawan sebagai imbalan atas pekerjaan mereka. Dari uraian di atas maka dapat disimpulkan bahwa kompensasi adalah suatu hak yang harus diberikan perusahaan kepada karyawan atas balas jasa yang dilakukannya agar karyawan tersebut dapat bekerja dengan baik dan harapan yang diinginkan perusahaan tercapai.

\section{Kepuasan Kerja}

Luthans (2005:243), mengemukakan bahwa kepuasan kerja adalah hasil dari persepsi pegawai mengenai seberapa baik pekerjaan mereka memberikan hal yang dinilai penting. Menurut Siagian (2003:295), kepuasan kerja merupakan suatu cara pandang seseorang baik yang bersifat positif maupun negatif tentang pekerjaannya. Sikap ini 
dicerminkan oleh moral kerja, kedisiplinan dan prestasi kerja. Berdasarkan uraian di atas, penulis menyimpulkan bahwa kepuasan kerja adalah perasaan yang dirasakan karyawan atas apa yang diperolehnya berdasarkan pekerjaan, dan sikap karyawan lain serta kondisi lingkungan yang mendukung pekerjaan yang akan dilakukannya.

\section{Pengaruh Motivasi dan Kompensasi Terhadap Kepuasan Kerja Karyawan}

Menurut Handoko (2003:193), menjadi kewajiban setiap pimpinan perusahaan untuk menciptakan kepuasan kerja bagi para pegawainya, karena kepuasan kerja merupakan faktor yang diyakini dapat mendorong dan mempengaruhi semangat kerja pegawainya yaitu dengan memotivasi pegawai, agar pegawai dapat bekerja dengan baik dan secara langsung akan mempengaruhi prestasi kerja pegawai. Menurut Mondy (2008:5), menyatakan kompensasi adalah pemberian balas jasa bagi "employers" maupun "employees" baik yang berupa uang (finansial) maupun yang tidak langsung (non finansial). Dengan defenisi tersebut maka dapat disadari bahwa pemberian kompensasi jelas akan dapat meningkatkan prestasi kerja, motivasi dan kepuasan kerja.

\section{PEMBAHASAN}

\section{Analisa}

\section{a. Deskriptif Kualitatif}

Adapun penetapan kriteria nilai rata-rata jawaban dari responden tersebut dimasukan kedalam kelas-kelas interval dimana penetuan intervalnya memakai rumus sebagai berikut:

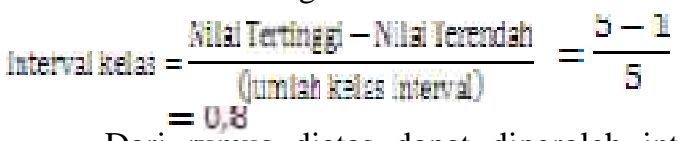

Dari rumus diatas dapat diperoleh interval kelas 0,8 sehingga berlaku ketentuan kategori dengan hasil sebagai berikut:

Tabel 2

Nilai Interval dan Kategori Jawaban Responden

\begin{tabular}{|c|c|c|c|}
\hline \multirow{2}{*}{ 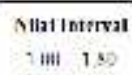 } & \multicolumn{3}{|c|}{ gen } \\
\hline & 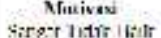 & 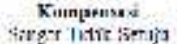 & 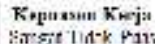 \\
\hline & & becs saviu & \\
\hline 4 & Surma thas & 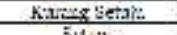 & KUIXEPU: \\
\hline$\frac{4--10}{1-50}$ & $\frac{\text { Baik }}{11 \text { iny Fyik }}$ & $\frac{5 t a n}{n=4}$ & 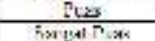 \\
\hline
\end{tabular}

Sumber: hasil pengolahan data

\section{1) Gambaran Motivasi Pada Kantor PT. PLN (Persero) Area Pematangsiantar}

Dari tabel jawaban responden untuk dimensi kebutuhan akan prestasi pada indikator usaha dalam mencari pengetahuan untuk mencapai prestasi kerja yang maksimal berada pada rata-rata 4,13 dengan kriteria jawaban baik dikarenakan pendidikan dan pelatihan karyawannya sangat rutin di laksanakan. Demikian juga pada indikator usaha dalam mencoba berbagai alternatif untuk meraih keberhasilan responden memberikan kriteria jawaban baik akan pertanyaan tersebut dan berada pada nilai 3,94 hal ini terjadi karena para karyawan hampir semua sudah memiliki pengetahuan lebih dalam membuat alternatif untuk menjalankan pekerjaannya, responden juga memberikan kriteria baik. Pada indikator kondisi kerja dengan sesama rekan kerjanya dengan kriteria rata-rata jawaban 4,24 hal ini karena komunikasi atau kerjasama antar sesama karyawan sudah sangat baik yang menyebabkan pekerjaan cepat terselesaikan dan lebih efisien.

Pada indikator antusiasme karyawan dalam mencapai prestasi yang tinggi, responden merespon baik dengan kriteria rata-rata jawaban 4,06 hal ini terjadi di karenakan para karyawannya mempunyai semangat untuk cepat mendapatkan prestasi yang tertinggi dalam perusahaaan. Untuk indikator usaha yang karyawan lakukan untuk memperoleh prestasi kerja agar memperoleh pendapatan yang besar, responden juga merespon baik dengan dengan kriteria rata-rata jawaban 4,01 karena para karyawan termotivasi untuk memperoleh prestasi kerja yang tinggi agar mendapat pendapatan yang tinggi.

Selanjutnya untuk dimensi kebutuhan akan afiliasi, pada indikator perasaan karyawan jika mendapatkan apresiasi dari pimpinan berada di ratarata 3,96 dengan kriteria jawaban baik, hal ini karena karyawan sudah memperoleh bentuk apresiasi yang sesuai dengan pekerjaan atas pelayanan yang diberikannya. Indikator tentang inisiatif karyawan dalam suatu pekerjaan dihargai oleh pimpinan, responden memberi respon 4,24 dengan kriteria jawaban sangat baik, hal ini disebabkan setiap inisiatif yang dilakukan karyawan menjadi bahan pertimbangan pimpinan dalam memberikan penghargaan dan menilai potensi diri karyawan.

Pada indikator tentang keefektifan kerja yang karyawan lakukan dengan bekerja sama bersama rekan kerja dengan kriteria rata-rata jawaban 3,99 yang artinya responden memberi respon dengan kriteria jawaban sangat baik juga, hal tersebut terjadi karena kerjasama antar karyawan yang terjadi sudah sangat baik sehingga para karyawan bisa saling memberi pendapat dalam menyelesaikan suatu pekerjaan. Dan pada indikator rasa kebanggaan karyawan dalam mengerjakan semua tugas tanpa harus takut gagal, responden juga memberikan respon pada nilai 3,94 dengan kriteria jawaban baik.

Selanjutnya untuk dimensi kebutuhan akan kekuasaan dengan indikator tentang usaha karyawan untuk memperoleh jabatan tertentu dengan meningkatkan semangat kerja responden memberikan respon baik dengan kriteria rata-rata jawaban 3,97. Kemudian indikator tentang usaha dalam menghadapi tantangan pekerjaan untuk meraih jabatan tertentu dengan kriteria rata-rata jawaban 3,96 yang artinya responden memberikan respon dengan kriteria jawaban baik, hal ini dikarenakan semua tugas yang diberikan perusahaan dapat diselesaikan dengan baik dan cepat sehingga para karyawan bisa mendapat kesempatan meraih jabatan yang lebih tinggi.

Untuk indikator tentang usaha untuk dapat bekerja demi mengharapkan jabatan tertentu responden memberi respon baik yang berada pada nilai 3,94 hal ini dikarenakan karyawan menginginkan jenjang karir yang lebih tinggi sehingga mereka sungguh-sungguh berusaha 
mencapai jenjang tersebut dengan berbagai usaha dan pengembangan diri. Demikian juga halnya indikator tentang usaha dalam mengikuti perkembangan iptek dalam menghadapi persaingan untuk meraih jabatan tertentu responden memberi respon dengan kriteria jawaban baik dengan kriteria rata-rata jawaban 4,01 hal ini dikarenakan para karyawan sudah di dukung dengan teknologi dalam persaingan antar karyawan untuk memperoleh jabatan tertentu.

Secara keseluruhan dapat dilihat bahwa ratarata motivasi yang diberikan kepada para responden berada pada nilai 4,03 dengan kriteria jawaban baik. Kemudian nilai rata-rata tertinggi sebesar 4,24 dengan kriteria nilai sangat baik pada dimensi tentang kebutuhan akan prestasi dengan indikator kerjasama sesama rekan kerja dan dimensi kebutuhan akan afiliasi dengan indikator inisiatif anda dalam suatu pekerjaan dihargai oleh pimpinan. Sedangkan nilai rata-rata terendah sebesar 3,94 dengan kriteria nilai baik pada dimensi kebutuhan akan prestasi dengan indikator usaha dalam mencoba berbagai alternatif untuk meraih keberhasilan, kebutuhan afiliasai dengan indikator rasa kebanggaan dalam mengerjakan pekerjaan tanpa harus takut gagal dan dimensi kebutuhan akan kekuasaan dengan indikator usaha anda dalam mengikuti perkembangan iptek dalam menghadapi persaingan untuk meraih jabatan.

\section{2) Gambaran Kompensasi Pada Kantor PT. PLN \\ (Persero) Area Pematangsiantar}

Untuk dimensi kompensasi finansial langsung dengan indikator memberikan gaji yang layak berada pada rata-rata 4,37 dengan kriteria jawaban sangat setuju, untuk indikator memberikan gaji yang adil berada pada rata-rata 4,24 responden juga memberikan kriteria rata-rata sangat setuju. Dan pada indikator gaji sesuai yang diinginkan berada pada rata-rata 3,99 dengan kriteria setuju, kategori gaji sesuai dengan jabatan responden menyatakan setuju pada rata-rata 4,09. Hal ini dikarenakan pemberian gaji yang berlaku di perusahaan berdasarkan golongan para karyawan, semakin tinggi jabatan yang ditanggung maka semakin besar pula gaji yang diterima karyawan tersebut.

Selanjutnya indikator gaji diberikan tepat waktu responden memberikan rata-rata jawaban 4,13 dengan jawaban setuju. Dan pada indikator bonus yang diberikan sesuai dengan harapan responden memberikan kriteria jawaban setuju dengan rata-rata 4,01 , pada indikator bonus diberikan sesuai dengan prestasi mendapat nilai rata-rata 4,32 dengan kriteria jawaban sangat setuju. Bonus diberikan secara adil responden memberikan rata-rata 4,32 dengan kriteria jawaban sangat setuju. Hal ini disebabkan karena karyawan ingin mendapatkan bonus sesuai dengan prestasi dan hasil kerja yang dilakukan secara maksimal dan baik bagi perusahaan diberikan secara adil kepada karyawan. Kemudian indikator bonus yang diberikan tepat waktu dengan kriteria jawaban setuju pada rata-rata 4,01 .
Untuk dimensi kompensasi finansial langsung dengan indikator tunjangan mencukupi kebutuhan responden menjawab dengan kriteria jawaban setuju nilai rata-rata 3,99 walaupun sudah dalam kriteria jawaban setuju masih ada yang memberikan jawaban sangat tidak setuju bahwa tunjangan yang diberikan diluar gaji belum mencukupi kebutuhannya. Indikator tunjangan diberikan dengan adil responden memberi nilai rata-rata 4,09 kriteria jawaban setuju. Tunjangan diberikan dengan layak responden memberi nilai rata-rata 4,13 kriteria jawaban setuju, indikator tunjangan yang diberikan sesuai lama bekerja diperoleh nilai rata-rata 4,13 dengan kriteria jawaban setuju. Perusahaan memberikan tunjangan sesuai jabatan para responden memberi nilai rata-rata 4,19 dengan kriteria jawaban setuju.

Pada dimensi kompensasi non finansial dengan indaktor fasilitas yang diberikan sudah mendukung dalam menyelesaikan pekerjaan responden memberikan nilai rata-rata 4,07 dengan kriteria jawaban setuju. Pada indikator ini walaupun sudah mencapai kriteria setuju tetapi masih ada yang memberikan jawaban sangat tidak setuju, hal ini dikarenakan karyawan tersebut merasa fasilitas kantor yang diberikan belum sepenuhnya mendukung dalam menyelesaikan pekerjaan. Indikator perusahan memberikan asuransi responden memberikan kriteria jawaban setuju dengan nilai rata 3,99. Dan indikator memberikan kebebasan dalam menjalankan tugas yang dikerjakan responden memberikan nilai rata-rata 4,10 dengan kriteria jawaban setuju.

Dari total jawaban responden mengenai kompensasi terdapat hasil yang berada pada rata-rata 4,13 dengan kriteria jawaban setuju. Kemudian nilai rata-rata tertinggi sebesar 4,37 pada dimensi kompensasi finansial langsung dengan indikator memberikan gaji yang layak dan nilai terendah sebesar 3,99 pada dimensi kompensasi finansial langsung dengan indikator gaji sesuai yang di inginkan, kompensasi finansial tidak langsung dengan indikator tunjangan mencukupi kebutuhan dan kompensasi non finansial dengan indikator asuransi. Walaupun sudah pada kriteria setuju, para pimpinan tetap harus memberikan kompensasi yang adil dan layak kepada karyawannya dan juga memperhatikan pemberian kompensasi yang diluar dari gaji seperti tunjangan, dan asuransi agar kepuasan karyawan dalam bekerja dapat terpenuhi.

\section{3) Gambaran Kepuasan Kerja Pada Kantor PT.}

PLN (Persero) Area Pematangsiantar

Dari jawaban responden dapat dilihat bahwa pada dimensi gaji dengan indikator gaji yang diterima berada pada rata-rata 3,97 dengan kriteria jawaban puas dikarenakan gaji yang diperoleh karyawan cukup untuk memenuhi kebutuhannya, selanjutnya indikator tentang tingkat kepuasan karyawan terhadap pemberian tunjangan yang diterapkan perusahaan berada pada rata-rata 4,24 dengan kriteria jawaban sangat puas, hal ini terjadi karena tunjangan yang di berikan oleh perusahaan bagi setiap karyawan cukup besar. Indikator 
pemberian gaji sesuai pekerjaan responden memberikan nilai rata-rata 4,09 dengan kriteria jawaban puas.

Indikator gaji yang diberikan sesuai jabatan jawaban responden memberikan kriteria jawaban puas dengan rata-rata 3,90 hal ini dikarenakan semakin tinggi jabatan yang ditanggung oleh karyawan tersebut maka gaji juga akan bertambah sesuai dengan jabatan yang diberikan. Untuk dimensi rekan kerja dengan indikator hubungan karyawan terhadap rekan kerja berada pada rata-rata 4,15 dengan kriteria jawaban puas dikarenakan antar sesama karyawan sudah mempunyai interaksi yang baik, hal itu menyebabkan komunikasi serta kerja sama antar karyawan sudah baik.

Selanjutnya dengan indikator perhatian antar sesama rekan kerja berada pada nilai rata-rata 4,09 dengan kriteria jawaban puas hal ini terjadi karena antar karyawan sudah seperti keluarga sendiri dimana jika ada karyawan yang kesulitan dibidang yang baru dia duduki maka karyawan lama yang menduduki bidang tersebut mau membantunya. Indikator kepuasan atas dukungan yang diberikan rekan kerja menyelesaikan pekerjaan berada pada nilai rata-rata 3,97 dengan kriteria jawaban puas hal ini karena kuatnya hubungan sesama rekan kerja sehingga dukungan yang diberikan sangat tinggi walaupun ada yang merasa tidak puas atas dukungan yang diberikan.

Untuk dimensi pimpinan pada indikator pengarahan yang diberikan atasan responden memberikan respon puas dengan kriteria rata-rata jawaban 3,90. Indikator tentang bimbingan yang diberikan pimpinan dalam melaksanakan tugas responden memberikan nilai rata-rata 3,90 dengan kriteria jawaban puas. Pada indikator perhatian yang diberikan atasan dalam melaksanakan tugas berada pada nilai 3,93 yang artinya responden memberikan kriteria jawaban puas, hal ini terjadi karena perhatian yang diberikan pimpinan sudah tinggi kepada karyawan dari masalah gaji, tunjangan dan segala fasilitas kantor lainnya.

Indikator pekerjaan yang diberikan atasan dalam melaksanakan tugas responden memberikan kriteria sangat puas dengan rata-rata 4,24 yang berarti pekerjaan yang diberikan atasan sudah baik dan sesuai bagi karyawan. Untuk dimensi pekerjaan itu sendiri pada indikator tentang sikap atas pekerjaan yang diberikan responden memberikan nilai rata-rata 3,97, selanjutnya indikator kenyamanan pekerjaan yang dikerjakan responden memberi nilai 3,97 dengan kategori puas hal ini dikarenakan karyawan sudah merasa nyaman dengan pekerjaan yang dilakukannya. Untuk indikator pekerjaan yang dikerjakan responden memberi respon puas dengan kriteria rata-rata jawaban 3,94, hal ini dikarenakan karyawan sudah menempati posisinya masing-masing sesuai dengan kemampuannya.

Selanjutnya pada indikator tentang kepuasan karyawan jika diberikan kesempatan mengembangkan keterampilan dalam pekerjaan responden memberi respon puas dengan kriteria rata- rata jawaban 3,82, hal ini dikarenakan para karyawan akan dihadapkan dengan persaingan antar karyawan untuk memperoleh jabatan tertentu. Untuk dimensi promosi pada indikator tentang kepuasan karyawan terhadap promosi berdasarkan kinerja responden memberikan respon puas dengan nilai 3,75 . Kemudian indikator promosi berdasarkan lama bekerja responden memberikan jawaban puas dengan kriteria rata-rata jawaban 3,90.

Indikator promosi yang diberikan berdasarkan prestasi kerja responden memberikan kriteria jawaban puas rata-rata 4,09. Pada dimensi lingkungan kerja indikator tentang kepuasan karyawan terhadap lingkungan kerja yang diberikan responden memberikan respon puas dengan kriteria rata-rata jawaban 3,97. Dan indikator tentang fasilitas yang diberikan responden memberikan jawaban puas dengan rata-rata 4,09. Walaupun sudah dalam kriteria puas, perusahaan harus tetap memfasilitasi karyawannya dengan peralatan yang modern sehingga pekerjaan cepat selesai dan karyawan yang merasa fasilitas yang diberikan kurang tidak ada lagi. Selanjutnya indikator kenyamanan kerja yang diberikan kriteria rata-rata jawaban 4,09 yang artinya responden memberikan jawaban puas.

Secara keseluruhan dapat dilihat bahwa untuk total jawaban responden mengenai kepuasan kerja karyawan baik dari segi gaji, rekan kerja, pimpinan/atasan, pekerjaan itu sendiri, promosi serta lingkungan kerja mendapat nilai rata-rata sebesar 4,00 dengan kriteria jawaban puas. Kemudian nilai rata-rata tertinggi sebesar 4,24 dengan kriteria jawaban sangat puas pada dimensi gaji dengan indikator pemberian tunjangan dan dimensi pimpinan/atasan dengan indikator pekerjaan yang diberikan atasan. Sedangkan nilai rata-rata terendah sebesar 3,75 dengan kriteria jawaban puas pada dimensi promosi dengan indikator promosi yang diberikan berdasarkan kinerja.

\section{b. Deskriptif Kuantitatif \\ 1) Regresi Linear Berganda}

Analisis dijalankan dengan melakukan tabulasi jawaban responden pada kuesioner yang telah dijalankan. Maka dilakukan perhitungan mengunakan program aplikasi SPSS untuk memperoleh nilai $a$ dan $b$ dengan notasi sebagai berikut : $\ddot{Y}=a+b_{1} X_{1}+b_{2} X_{2}$ ......(Simbolon, 2009:239) Tabel 3

Regresi Linier Berganda Coefficients $^{a}$

\begin{tabular}{|c|c|c|c|}
\hline \multirow[b]{2}{*}{ anded } & \multicolumn{2}{|c|}{ 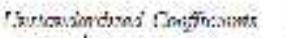 } & 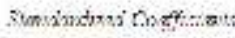 \\
\hline & $\mathrm{B}$ & Sta. Znvo & Bsta \\
\hline Coustari & t..98:? & 8130 & \\
\hline Matizant & .524 & 157 & 37 \\
\hline Karmetas: i & 25 & 116 & 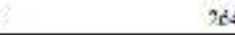 \\
\hline
\end{tabular}

a. Dependent Variable: Kepuasan Kerja

Sumber: data primer hasil pengolahan data SPSS Versi 17 
Berdasarkan hasil pengolahan data pada tabel 18 diatas diperoleh model persamaan $\hat{Y}=43,983+$ $0,424 \mathrm{X}_{1}+0,253 \mathrm{X}_{2}$, diartikan terdapat pengaruh yang positif antara variabel motivasi $\left(\mathrm{X}_{1}\right)$ dan kompensasi $\left(\mathrm{X}_{2}\right)$ terhadap variabel kepuasan kerja karyawan $(\mathrm{Y})$ pada Kantor PT. PLN (Persero) Area Pematangsiantar.

\section{2) Analisis Korelasi dan Koefisien Determinan}

Hasil koefisien korelasi dan koefisien determinasi dapat dilihat pada tabel berikut ini: Tabel 4

Koefisien Korelasi dan Koefisien Determinasi Model Summary ${ }^{b}$

\begin{tabular}{|c|c|c|c|c|}
\hline Aucal & $\mathrm{K}$ & R. Syan, & Akjialok K Yquary & 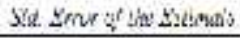 \\
\hline . & 521 & .275 & .253 & 7.30780 \\
\hline
\end{tabular}

a. Predictors: (Constant), (Motivasi) (Kompensasi) b. Dependent Variable: (Kepuasan Kerja)

Sumber: data primer hasil pengolahan kuesioner menggunakan SPSS Versi 17.

Dari hasil koefisien korelasi pada tabel 19 di atas diperoleh nilai $r=0,524$, yang artinya terdapat hubungan yang sedang dan positif antara motivasi, kompensasi dan kepuasan kerja karyawan pada kantor PT. PLN (Persero) Area Pematangsiantar, sesuai dengan kriteria tingkat hubungan pada tabel 5 . Kemudian diperoleh nilai koefisisen determinasi ( $\mathrm{R}$ Square) $=0,275$, artinya tinggi rendahnya kepuasan kerja karyawan (Y) pada kantor PT PLN (Persero) Pematangsiantar sebesar 27,5\% dapat dijelaskan oleh motivasi $\left(\mathrm{X}_{1}\right)$ dan kompensasi $\left(\mathrm{X}_{2}\right)$, sedangkan sisanya sebesar $72,5 \%$ dipengaruh oleh faktor lain seperti lingkungan kerja, kinerja, komunikasi, kepemimpinan dan sebagainya yang tidak dibahas dalam penelitian ini.

\section{3) Uji Simultan (Uji F)}

Dari hasil perhitungan koefisien korelasi diketahui bahwa Motivasi, Kompensasi dan Kepuasan kerja sangat berhubungan, untuk menguji kebenarannya maka dilakukan pengujian hipotesis dengan menggunakan program aplikasi SPSS Versi 17

Tabel 5

Perkiraan Nilai $F$ hitung

\begin{tabular}{|c|c|c|c|c|c|c|}
\hline & & & & & \\
\hline \multirow{3}{*}{$\begin{array}{ll}\mathrm{Mm} \\
\mathrm{I}\end{array}$} & & 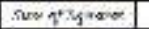 & $\pi$ & 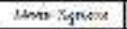 & 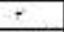 & \\
\hline & Resul..:st & D16:58 & & 5.22 & 12.526 & \\
\hline & Pentidal & an 2120 & 6 & $53<04$ & & \\
\hline & Tor: & $437-\infty$ & 6 & & & \\
\hline
\end{tabular}

a." Predictor: (Constant), Motivasi, Kompensasi

b. Dependent Variable: Kepuasan Kerja

Sumber: data primer hasil pengolahan kuesioner menggunakan SPSS Versi 17

Berdasarkan diatas diperoleh nilai $f_{\text {hitung }}$ sebesar 12,326 sedangkan $\mathrm{f}_{\text {tabel }}$ dengan $(0,05 ; 2$ vs 65) sebesar 3,14, atau dengan taraf signifikan 0,000 $<\quad \alpha 0,05$, maka $\mathrm{H}_{0}$ ditolak, artinya motivasi dan kompensasi berpengaruh positif dan signifikan terhadap kepuasan kerja karyawan pada kantor PT. PLN (Persero) Area Pematangsiantar secara simultan.

\section{4) Uji Parsial (Uji t)}

Dari hasil perhitungan koefisien korelasi diketahui bahwa Motivasi, Kompensasi dan Kepuasan Kerja karyawan sangat berhubungan, untuk menguji kebenarannya maka dilakukan pengujian hipotesis dengan menggunakan program aplikasi SPSS Versi 17.

Tabel 6

Perkiraan Nilai thitung Coefficients $^{a}$

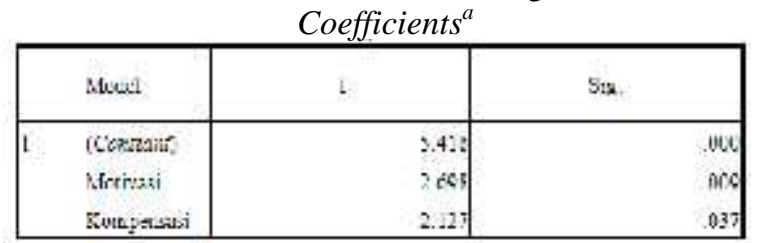

a. Dependent Variable: kepuasan kerja

Sumber: data primer hasil pengolahan kuesioner menggunakan SPSS Versi 17

Berdasarkan tabel diatas diperoleh nilai $t_{\text {hitung }}$ pada variabel $\mathrm{X}_{1}$ (motivasi) sebesar 2,698 sedangkan $\mathrm{t}_{\text {tabel }}$ dengan $\mathrm{df}=\mathrm{n}-\mathrm{k}-1(68-2-1=65)$ sebesar 1,9971, atau dengan taraf signifikan $0,009<\alpha 0,05$, maka $\mathrm{H}_{0}$ ditolak dan $\mathrm{H}_{\mathrm{a}}$ diterima, artinya motivasi berpengaruh positif dan signifikan terhadap kepuasan kerja karyawan pada kantor PT. PLN (Persero) Area Pematangsiantar secara parsial. Variabel $\mathrm{X}_{2}$ (kompensasi) $\mathrm{t}_{\text {hitung }}$ sebesar 2,127 sedangkan $\mathrm{t}_{\text {tabel }}$ dengan $\mathrm{df}=\mathrm{n}-\mathrm{k}-1,(68-2-1=65)$ sebesar 1,9971, atau dengan taraf signifikan $0,037<$ $\alpha 0,05$, maka $\mathrm{H}_{0}$ ditolak dan $\mathrm{H}_{\mathrm{a}}$ diterima, artinya kompensasi berpengaruh positif dan signifikan terhadap kepuasan kerja karyawan pada kantor PT. PLN (Persero) Area Pematangsiantar secara parsial.

\section{Evaluasi}

\section{a. Motivasi Pada Kantor PT. PLN (Persero)} Area Pematangsiantar

Dilihat dari hasil kuisioner yang dibagikan kepada responden mendapat nilai rata-rata keseluruhan sebesar 4,03 dalam kreteria baik. Namun ada beberapa aspek walaupun dinilai baik tetapi masih ada yang dinilai dibawah rata-rata dari indikator-indikator lain, yang pertama dimensi kebutuhan akan prestasi dengan indikator usaha dalam mencoba berbagai alternatif untuk meraih keberhasilan memperoleh nilai 3,94. Untuk mengatasi hal ini sebaiknya para karyawan harus lebih meningkatkan pengetahuan yang lebih lagi dalam membuat alternatif untuk menjalankan pekerjaannya.

Untuk dimensi kebutuhan akan afiliasi dengan indikator hasil pelayanan mendapat apresiasi dari pimpinan memperoleh nilai 3,96. Walaupun karyawan sudah memperoleh bentuk apresiasi yang sesuai dengan pelaksanaan pekerjaannya namun nilai yang diperoleh jauh dari nilai rata-rata keseluruhan indikator, dan cara mengatasinya yaitu pimpinan harus memberikan apresiasi yang lebih agar tingkat pelayanan yang diberikan karyawan lebih maksimal lagi. Selanjutnya indikator keefektifan kerja yang dilakukan dengan bekerjasama memperoleh nilai 3,99 dengan jawaban baik. Pada indikator rasa kebanggaan dalam mengerjakan semua tugas tanpa 
harus takut gagal memperoleh nilai 3,94. Cara meningkatkannya ialah pimpinan haruslah memberikan masukan agar para karyawan memperoleh kepercayaan diri yang tinggi dalam mengerjakan pekerjaannya.

Selanjutnya dimensi kebutuhan akan kekuasaan pada indikator usaha anda untuk memperoleh jabatan tertentu dengan meningkatkan semangat kerja memperoleh nilai 3,97. Indikator usaha untuk dapat bekerja demi mengharapkan jabatan memperoleh nilai 3,94. Dan terakhir pada indikator usaha dalam mengikuti perkembangan iptek dalam menghadapi persaingan untuk meraih jabatan tertentu memperoleh nilai 4,01. Dari dimensi kebutuhan akan kekuasaan di atas para responden menjawab dengan rata-rata kriteria baik. Walaupun sudah dikategorikan baik, dalam hal ini pimpinan juga tetap harus memberikan keyakinan kepada karyawan agar mencapai prestasi kerja yang tinggi dan bersemangat mengikuti perkembangan teknologi sehingga jabatan yang diinginkan dapat tercapai.

Dari evaluasi motivasi diatas dapat diambil kesimpulan jika semua hal-hal diatas sudah dinyatakan dengan baik, karyawan akan merasa puas terhadap motivasi yang diberikan pimpinan dan mereka mampu meraih prestasi yang tinggi serta dapat memperoleh apresiasi atau penghargaan yang tinggi dari pimpinan menurut pekerjaannya masingmasing.

\section{b. Kompensasi Pada Kantor PT. PLN (Persero) Area Pematangsiantar}

Berdasarkan dimensi yang digunakan dan hasil penelitian yang diperoleh dapat dijelaskan bahwa kompensasi yang ada pada kantor PT. PLN (Persero) Area Pematangsiantar sudah dalam kategori setuju, hal ini dapat dilihat dari kompensasi finansial langsung, tidak langsung, dan non finansial. Hal tersebut dapat dibuktikan dengan nilai rata-rata dari kompensasi tersebut sebesar 4,13 dengan kriteria jawaban setuju. Namun masih ada beberapa aspek-aspek walaupun sudah dalam kriteria setuju tetapi masih rendah dibawah nilai rata-rata.

Pertama pada dimensi kompensasi finansial langsung indikator gaji sesuai dengan keinginan memperoleh nilai 3,99 dengan kriteria jawaban setuju. Dalam hal ini dapat dilihat bahwa banyak yang kurang setuju atas gaji yang diterima sesuai dengan keinginan karena dapat berdampak bagi kinerja karyawan yang menurun, dan cara mengatasinya perusahaan harus dapat memberikan gaji sesuai dengan apa yang dikerjakan dan jabatan yang ditanggung karyawan tersebut. Selanjutnya pada indikator gaji sesuai dengan jabatan memperoleh nilai 4,09 masih dibawah nilai rata-rata seluruhnya. Untuk meningkatkannya perusahaan harus memberikan gaji sesuai dengan jabatan yang ditanggung oleh karyawan itu tersebut.

Berikutnya pada indikator bonus sesuai dengan yang diharapkan memperoleh nilai sebesar 4,01. Untuk dapat meningkatkannya yaitu perusahaan harus dapat memberikan pengarahan dan bimbingan kepada karyawannya, karena bonus yang tinggi harus sesuai dengan prestasi dan hasil kerja yang tinggi. Indikator bonus anda terima tepat waktu memperoleh nilai 4,01. Cara meningkatkannya yaitu dengan memberikan bonus sesuai dengan waktu pemberiannya sehingga tidak ada lagi karyawan yang merasa bonus yang diberikan tidak tepat pada waktunya.

Pada dimensi kompensasi finansial tidak langsung indikator tunjangan mencukupi kebutuhan memperoleh nilai rata-rata sebesar 3,99 untuk meningkatkannya perusahaan harus memberikan tunjangan yang adil dan layak sehingga kebutuhan karyawan dapat terpenuhi. Indikator perusahaan memberikan tunjangan yang adil memperoleh nilai 4,01. Sama seperti indikator sebelumnya dalam hal ini perusahaan harus memperhatikan apakah tunjangan yang diberikan sudah adil dan layak diterima oleh karyawan tersebut.

Selanjutnya pada dimensi kompensasi non finansial indikator fasilitas kantor memperoleh nilai sebesar 4,07. Cara meningkatkannya yaitu dengan memperbaharui fasilitas kantor yang sudah usang agar karyawannya dapat bekerja dengan cepat. Indikator asuransi responden memberikan nilai ratarata sebesar 3,99. Untuk meningkatkannya yaitu perusahaan harus dapat memberikan asuransi yang sesuai dengan kebutuhan yang dibutuhkan oleh karyawannya.

Dalam hal ini dapat dilihat bahwa pemberian kompensasi pada kantor PT. PLN (Persero) Area pematangsiantar sudah dikategorikan setuju. Walaupun sudah dalam kategori setuju perusahaan harus memberikan kompensasi yang tepat dan sesuai dengan kebutuhan karyawan tersebut sehingga memberikan kepuasan tersendiri kepada karyawan tersebut dan juga keinginan mendapat kompensasi yang tinggi juga lebih besar.

\section{c. Kepuasan Kerja Pada Kantor PT. PLN (Persero) Area Pematangsiantar}

Dimensi gaji pada indikator gaji yang diterima memperoleh nilai 3,97. Hal ini disebabkan karena masih ada karyawan yang merasa kurang puas terhadap gaji yang diterimanya cara mengatasinya ialah dengan menaikkan gaji para karyawan sesuai dengan prosedur dan peraturan perusaahaan tersebut.

Indikator gaji yang diberikan sesuai dengan jabatan memperoleh nilai 3,90. Cara meningkatkannya, perusahaan memberikan kenaikan gaji yang sesuai dengan jabatan karyawan tersebut dan juga tidak menyalahi aturan yang ada pada perusahaan. Selanjutnya pada dimensi rekan kerja dengan indikator dukungan yang diberikan rekan kerja dalam menyelesaikan pekerjaan memperoleh nilai 3,93 dan cara meningkatkannya yaitu dengan memberikan pekerjaan yang dilakukan bersama sehingga dukungan untuk menyelesaikan pekerjaan tersebut bisa lebih tinggi. Dan pada dimensi pimpinan/atasan dengan indikator pengarahan yang diberikan pimpinan memperoleh nilai rata-rata sebesar 3,90. Cara untuk meningkatkannya yaitu pimpinan harus memberikan pengarahan yang sesuai 
dengan kebutuhan karyawan agar karyawan tersebut dapat bekerja dengan baik. Indikator bimbingan yang diberikan atasan memperoleh nilai sebesar 3,90. Hal ini disebabkan karena kurangnya bimbingan yang diberikan pimpinan kepada karyawannya dan cara meningkatkannya pimpinan harus lebih memperhatikan serta membimbing karyawannya agar kinerja dari karyawan tersebut dapat meningkat.

Indikator perhatian yang diberikan pimpinan memperoleh nilai rata-rata sebesar 3,93. Untuk meningkatkannya perusahaan dalam hal ini pimpinan/atasan harus dapat memberikan pengarahan, bimbingan serta perhatian dengan baik sehingga karyawan tersebut tidak ada lagi yang merasa kurang puas atas apa yang dilakukan pimpinan. Selanjutnya untuk dimensi pekerjaan itu sendiri pada indikator sikap terhadap pekerjaan yang diberikan memperoleh nilai rata-rata sebesar 3,97. Cara meningkatkannya adalah perusahaan memberikan motivasi dan kompensasi yang baik sesuai dengan kebutuhan karyawan tersebut sehingga setiap pekerjaan yang diberikan perusahaan untuk dikerjakan dapat dilakukan dengan sikap yang baik dan kepuasan dalam bekerja dapat meningkat.

Indikator kenyamanan dalam bekerja memperoleh nilai rata-rata sebesar 3,97 cara meningkatkannya yaitu perusahaan memberikan sedikit kebebasan sehingga karyawan tidak merasa tertekan dalam menyelesaikan pekerjaan tersebut. Selanjutnya indikator pekerjaan yang diberikan memperoleh nilai rata-rata sebesar 3,94 dan cara meningkatkannya yaitu perusahaan memberikan pelatihan setiap pertriwulannya sehingga pekerjaan yang diberikan dapat dikerjakan dengan cepat dan baik. Indikator kesempatan yang diberikan dalam mengembangkan keterampilan memperoleh nilai rata-rata sebesar 3,82. Cara meningkatkannya ialah dengan memberikan keleluasaan yang lebih lagi bagi karyawan dalam hal peningkatan keterampilan agar terciptanya para karyawan yang kreatif dan terampil.

Selanjutnya untuk dimensi promosi pada indikator promosi yang diberikan berdasarkan kinerja memperoleh nilai rata-rata sebesar 3,75. Cara meningkatkannya yaitu lebih banyak memberikan kesempatan promosi bagi karyawan yang berprestasi dalam pekerjaannya. Untuk indikator promosi yang diberikan berdasarkan lamanya bekerja memperoleh nilai rata-rata sebesar 3,90. Cara meningkatkannya yaitu memberikan kesempatan promosi bagi karyawan yang berprestasi lebih banyak lagi dan juga mendukung karyawan yang sudah lama bekerja untuk dapat meningkatkan prestasi kerja sehingga pemberian promosi dapat diberikan.

Selanjutnya untuk dimensi lingkungan kerja pada indikator limgkungan kerja yang diberikan memperoleh nilai rata-rata sebesar 3,97. Cara untuk meningkatkannya yaitu menciptakan lingkungan kerja yang kondusif dan lebih lebih aman lagi serta lebih memperhatikan tata letak ruang kantornya. Kepuasan kerja merupakan perasaan yang dirasakan karyawan atas apa yang diperolehnya berdasarkan pekerjaan, dan sikap karyawan lain serta kondisi lingkungan yang mendukung pekerjaan yang akan dilakukannya. Karena kepuasan kerja merupakan faktor yang diyakini dapat mendorong dan juga mempengaruhi semangat kerja karyawan agar karyawan dapat bekerja dengan baik dan secara langsung dapat mempangaruhi prestasi kerja.

\section{KESIMPULAN DAN SARAN}

\section{Kesimpulan}

a. Dari hasil analisis deskriptif kualitatif tentang motivasi berdasarkan dimensi kebutuhan akan prestasi, kebutuhan akan afiliasi, kebutuhan akan kekuasaan memperoleh rata-rata jawaban keseluruhan 4,03 dengan kriteria baik. Kemudian nilai rata-rata tertinggi sebesar 4,24 dengan kriteria nilai sangat baik pada dimensi kebutuhan akan prestasi dengan indikator kondisi kerjasama dengan sesama rekan kerja dan kebutuhan akan afiliasi dengan indikator inisiatif anda dalam suatu pekerjaan dihargai oleh pimpinan. Sedangkan kelemahan dengan nilai rata-rata sebesar 3,94 dengan kriteria nilai baik pada dimensi kebutuhan akan prestasi dengan indikator usaha dalam mencoba berbagai alternatif untuk meraih keberhasilan, kebutuhan akan afiliasi dengan indikator rasa kebanggaan dalam mengerjakan semua tugas tanpa harus takut gagal dan kebutuhan akan kekuasaan dengan indikator usaha untuk dapat bekerja demi mengharapkan jabatan tertentu.

b. Dari hasil analisis deskriptif kualitatif tentang kompensasi berdasarkan dimensi kompensasi finansial langsung, tidak langsung dan non finansial memperoleh rata-rata jawaban keseluruhan 4,13 dengan kriteria setuju. Kemudian nilai rata-rata tertinggi sebesar 4,37 dengan kriteria nilai sangat setuju pada dimensi kompensasi finansial langsung dengan indikator gaji yang layak. Sedangkan kelemahan dengan nilai rata-rata sebesar 3,99 dengan kriteria jawaban setuju pada dimensi kompensasi finansial langsung dengan indikator gaji sesuai dengan keinginan. Kompensasi finansial tidak langsung dengan indikator tunjangan mencukupi kebutuhan dan dimensi kompensasi non finansial dengan indikator perusahaan memberikan asuransi.

c. Dari hasil analisis deskriptif kualitatif tentang kepuasan kerja karyawan berdasarkan dimensi gaji, rekan kerja, pimpinan/atasan, pekerjaan itu sendiri, promosi, lingkungan kerja memperoleh rata-rata jawaban keseluruhan 4,00 dengan kriteria puas. Kemudian nilai rata-rata tertinggi sebesar 4,24 dengan kriteria nilai sangat puas pada dimensi gaji dengan indikator pemberian tunjangan yang diterapkan perusahaan. Dimensi pimpinan/atasan dengan indikator pekerjaan yang diberikan atasan. Sedangkan kelemahan dengan nilai rata-rata sebesar 3,75 dengan kriteria nilai puas pada dimensi promosi dengan indikator promosi yang diberikan berdasarkan kinerja.

d. Hasil analisis regresi linear berganda yang dihitung melalui program SPSS versi 17 sebagai berikut $\hat{\mathrm{Y}}=43,983+0,424 \mathrm{X}_{1}+0,253 \mathrm{X}_{2}$ 
diartikan terdapat pengaruh yang positif antara variabel motivasi $\left(\mathrm{X}_{1}\right)$ dan kompensasi $\left(\mathrm{X}_{2}\right)$ terhadap variabel kepuasan kerja karyawan (Y) pada Kantor PT. PLN (Persero) Area Pematangsiantar.

e. Hasil analisis korelasi diperoleh nilai $\mathrm{r}$ sebesar 0,524 yang artinya terdapat hubungan yang sedang dan positif antara motivasi $\left(\mathrm{X}_{1}\right)$ dan kompensasi $\left(\mathrm{X}_{2}\right)$ terhadap kepuasan kerja karyawan (Y) pada Kantor PT. PLN (Persero) Area Pematangsiantar. Kemudian diperoleh nilai koefisisen determinasi $(\mathrm{R}$ Square $)=0,275$, artinya tinggi rendahnya kepuasan kerja karyawan (Y) pada Kantor PT. PLN (Persero) Area Pematangsiantar sebesar $27,5 \%$ dapat dijelaskan oleh motivasi $\left(\mathrm{X}_{1}\right)$ dan kompensasi $\left(\mathrm{X}_{2}\right)$, sedangkan sisanya sebesar $72,5 \%$ dipengaruh oleh faktor lain yang tidak dibahas dalam penelitian ini seperti lingkungan kerja, kinerja, komunikasi, kepemimpinan dan lain-lain.

f. Melalui pengujian hipotesis dengan uji $F$ (uji simultan), terdapat pengaruh yang positif dan signifikan antara variabel motivasi dan kompensasi terhadap kepuasan kerja karyawan, dimana nilai $\mathrm{f}_{\text {hitung }}$ sebesar 12,326 sedangkan $\mathrm{f}_{\text {tabel }}$ dengan $(0,05 ; 2$ vs 65$)$ sebesar 3,14 , atau dengan taraf signifikan sebesar $0,000<\alpha 0,05$, maka $\mathrm{H}_{\odot}$ ditolak, artinya motivasi dan kompensasi berpengaruh positif dan signifikan terhadap kepuasan kerja karyawan pada kantor PT. PLN (Persero) Area Pematangsiantar

g. Melalui pengujian hipotesis dengan uji t (uji parsial), terdapat pengaruh yang positif dan signifikan antara variabel motivasi dan kompensasi terhadap kepuasan kerja karyawan, diperoleh nilai $t_{\text {hitung }}$ pada variabel motivasi $\left(\mathrm{X}_{1}\right)$ sebesar 2,698 sedangkan $t_{\text {tabel }}$ dengan $\mathrm{df}=\mathrm{n}-\mathrm{k}-1$ (68-2-1=65) sebesar 1,9971, atau dengan taraf signifikan sebesar $0,009<\alpha 0,05$, maka $\mathrm{H}_{\circ}$ ditolak, artinya motivasi berpengaruh positif dan signifikan terhadap kepuasan karyawan pada kantor PT. PLN (Persero) Area Pematangsiantar. Sedangkan untuk variabel kompensasi $\left(\mathrm{X}_{2}\right)$ diperoleh nilai $t_{\text {hitung }}$ sebesar 2,127 sedangkan $\mathrm{t}_{\text {tabel }}$ dengan $\mathrm{df}=\mathrm{n}-\mathrm{k}-1 \quad(68-2-1=65)$ sebesar 1,9971, atau dengan taraf signifikan sebesar $0,037<\alpha 0,05$, maka $\mathrm{H}_{\circ}$ ditolak, artinya kompensasi berpengaruh positif dan signifikan terhadap kepuasan kerja karyawan pada kantor PT. PLN (Persero) Area Pematangsiantar.

\section{Saran}

a. Untuk meningkatkan motivasi pada Kantor PT. PLN (Persero) Area Pematangsiantar perlu dilakukan pemberian pengetahuan dalam membuat alternatif untuk menjalankan pekerjaan, pimpinan memberikan apresiasi terhadap pelayanan, mengikuti perkembangan teknologi, dan memberikan masukan agar karyawan percaya diri dalam menyelesaikan pekerjaan.

b. Untuk meningkatkan kompensasi pada Kantor PT. PLN (Persero) Area Pematangsiantar perusahaan harus memberikan gaji sesuai dengan jabatan dan pekerjaan yang dilakukan, memberikan pengarahan dan bimbingan, memberikan bonus tepat pada waktunya, memberikan tunjangan secara adil dan layak. Memperbaharui fasilitas kantor yang sudah usang, dan memberikan asuransi sesuai dengan kebutuhan karyawan.

c. Untuk meningkatkan kepuasan kerja karyawan pada Kantor PT PLN (Persero) Area Pematangsiantar harus memberikan promosi atau kenaikan jabatan bagi karyawan yang berprestasi diatas dari standar perusahaan.

d. Sehubungan dengan keterbatasan-keterbatasan yang ada pada penulis, penelitian ini masih terdapat kelemahan-kelemahan dan belum dapat mengungkap seluruh variabel yang dapat mempengaruhi kepuasan karyawan pada Kantor PT. PLN (Persero) Area Pematangsiantar. Sebagai bahan masukan untuk penelitian selanjutnya, perlu memperbanyak variabel penelitian, seperti seperti lingkungan kerja, kinerja, komunikasi, kepemimpinan dan lain-lain.

\section{E. DAFTAR PUSTAKA}

Dessler, Gary. 2007. Manajemen Sumber Daya Manusia, Edisi II. Jakarta: PT. Indeks.

Griffin, Ricky W. 2004. Manajemen, Jilid I, Edisi 7. Jakarta: Erlangga.

Handoko, T. Hani. 2003. Manajemen, Edisi Kedua. Yogyakarta: BPFE Kotler, Philip dan Gary Amstrong. 2004. Dasar-Dasar Pemasaran. Edisi Kesembilan. Jakarta: PT Indeks.

Luthans, Fred. 2006. Perilaku Organisasi, Edisi 10. Yogyakarta: ANDI.

........, 2005. Perilaku Organisasi, Edisi kesepuluh. Yogyakarta: ANDI.

Mondy, R. Wayne. 2008. Manajemen Sumber Daya Manusia, Edisi 10. Jilid I, Jakarta: Erlangga.

Robbins, Stephen P dan Timothy A Judge, 2008, Perilaku Organisasi, Jakarta: Salemba Empat.

Robbins, Stephen P, 2003, Manajemen Jilid I, Jakarta: PT. Indeks.

Siagian, Sondang P, 2003, Manajemen Sumber Daya Manusia, Jakarta: Erlangga.

Simbolon, Hotman. 2009, Statistika, Jakarta: Salemba Empat. 